\begin{tabular}{ll}
\hline \hline MINING AND METALLURGY INSTITUTE BOR & ISSN: 2334-8836 (Štampano izdanje) \\
UDK: 622 & ISSN: 2406-1395 (Online) \\
\hline \hline
\end{tabular}

\title{
CHARACTERISTICS OF THE PROJECT FINANCE IN THE REPUBLIC OF SERBIA
}

\begin{abstract}
Nowadays, the project finance is applied both in undeveloped and highly developed economies, including Serbia. In the current practice of the project finance in Serbia and Europe, the project finance has usually been used for intensive capital activities, therefore the aim of this study is to apply all experiences gained on those projects, not only in our country. It is pointed out hereby to superiority of this kind of finances together with all risks it takes, and what is needed to make it more attractive under the current economic conditions and circumstances. Moreover, the effectiveness and efficiency of using this model of finances requires the economic sustainability of concrete projects through the positive impacts on entire social and economic development, especially of Serbia. The analytic and synthetic methods, as well as the classification method were used in this research as the fundamental scientific methods, whereas the methods of analytic-deductive and comparative methods were used as the general scientific methods.
\end{abstract}

Keywords: project, investments, economic development, energy

\section{INTRODUCTION}

Project finance is also known as the structured finance, since it requires such structure of debt and shareholders' equity enabling the cash flow of the project to be adequate to the service of debt.

In practice, the project finance is usually used for capital intensive activities when the ones responsible for a project are the loan insolvent for traditional forms of financing or are not ready to take risks and loan commitments. In the project finance model, total risks of the project are distributed to several partners, and thus risks are decreased to the level acceptable to each partner. [1].

Quantitative methodologies support project finance and include simulation and techniques of finance engineering. They optimize the structure of capital and eva- luate financial variability of projects, under risky circumstances, especially when the project implementation is associated to the constructive risk, risk of potential bankruptcy, economic crisis, as well as the other limitations created as a result of lack of capital.

Project finance is such a model of project financing based on the analysis of project justification, since only the projects generating income during the project enabling service of invested funds are regarded acceptable. Therefore, negotiations which follow the project finance should meet the common interests of various parties, thus the anticipated economic profit of each participant is proportional to the risk associated to the project implementation.

\footnotetext{
*Higher Economic Professional School Pec in Leposavic, 24. November Street, e-mail: savic22@yahoo.com
} 
Nelge Switala (2010) points out that establishment of a special project company and predictability of future cash flows are the most prominent characteristics of the project finance. According to this author, there is a serial of other characteristics, such as: conceding all rights of debtors to creditors regarding the project which is being funded; inclusion of so-called "partner" with interest; contract distributes structure of risk among all parties; ban of additional debts; commercial value of project may outlive downfall of one sponsor, supplier, contactor. [2].

Gatti Stefano points out in this regard that the most important characteristics of the project finance are: supervision and money investment with interest and repayment. It seems that the project finance may be defined in the best manner as a method of financing where, when it comes to service of debt and investment profit, the "creditors" investors are exclusively or predominantly focused on cash flows created by the funded project. Essentially, the project finance is based on transfer of risk regarding certain funded project at the expense of the financier [3].

\section{GENESIS OF THEORETICAL FINDINGS OF THE PROJECT FINANCE}

With regards to genesis of theoretical findings of the project finance, the financial literature about this issue is still in the initial phase of formation. Analyses of the project finance (assumptions and justifications) are also in the initial phase. Nowadays, the project finance has become a big business in the world. It is also important as a manner of financing economic development in entire world; however, there are very few researches within academic theory and researches of project finance itself. Worenklen is one of the theoreticians who left a mark on definition the project finance. This author deems that the project demand, with sources of credit support, has to be put in form of a contract. In more details, Worenklen (1981) underlines that in order to attract investors for the new capacities needed in the future, the regulations are to help and to create stability in which the investor expectations will be met. The author proposes a new model of public-private partnership for the poorest countries. Such model, according to this author, will encourage the initiative and creativity of the private sector. [4]. According to Dasu (Das, 2006), most of infrastructural projects may be regarded as the greenfield projects [5], since they started as a publicprivate partnership.

According to Nevitu and Fabozziu, the term project finance is defined as the project financing where a creditor will be satisfied that service of debt is initially done from cash flows, and later from profit produced by the project [6]. Project finance may be sometimes used to increase invested capital as optimal as possible adjusting the investment and expenditures ensuing from the project itself. They are, in a way, opponents to the concept of project finance, since, according to them, the project finance foresees greater shareholder risks and does not provide convincing reason to use such model of financing. [7]. Under those circumstances, Smith and Warner, propose some kind of monitoring for the project finance, since it allows more detailed control to leaders over company management. For Smith and Warnera (1979) and Rajan and Winter (1995), monitoring at project finance is very important, since it includes and enables detailed control to leaders over management [3]. Smith and Warner concretely suggest that by defining hypothesis of shareholders control in a contract may increase value of a company. Hypothesis in the contract should contain prohibitions for companies that have a role of debtors in loan agreements. Smith 
and Warner (1979) underline that the public debt is present at project finance, Berdli and Roberts (2003) say that the project finance contains a private debt, Kaplan and Stromberg (2003) say that the private capital is essence of the project finance [8].

Shah and Thakor (1987) are the first authors who analyzed the project finance for large and highly risky projects. Those two authors claim that the project companies may work in scope of good economic institutions. On the other hand, in the unstable environments, the project companies need to refer not only to the agencies, but also to the other institutions in order to protect their rights. So, according to these authors, the basic motivation is to empirically study potential impact of factors that contribute to efficient management of debt capacity in project companies under circumstances where there is poor institutional environment. [8].

In the world, the project finance is a fast growing field of large capital investments for large and other infrastructural projects. If trends of the project finance growth are followed, it has tendency of growing according to all indicators. That growth is manifested in such a way that there were 541 projects financed with 180 billion USA do- llars in total in the world in 2006. This trend was significantly higher in 2010 with 58 projects financed with total 206 billion USA dollars, despite deterioration of economic crisis in that moment. Vepjatin Esty was very concrete when indicated that the growth of project finance went from less than 10 billion USA dollars annually in the world during 1980's to almost 220 billion USA dollars in 2001[9]. Contrary to previous theoreticians, Shep, Kepsinger and Martin (1989) prefer thesis that the project finance is widely used for the low risk projects of medium size [3].

It seems that the fastest growing filed through the project finance model is an investment into energy. Other models that show a growth tendency are the infrastructural projects, not only in developed, but also in developing economies. All of these is aimed to creating the necessary infrastructure to generally improvement the lives of citizens. In the world, the project finance has been successfully implemented in the following sectors: infrastructure, water pipe lines with factories for waste water processing, roads, railways, ports and airports, energy, telecommunications, mining, industry, tourism, public services (schools, hospitals, public lightening, etc.).

Table 1 Trend of the project finance growth in the world in 2010 (in USA dollars) [10]

\begin{tabular}{|c|c|c|}
\hline State & Project value & Number of loans \\
\hline Spain & 174 billion of dollars & 67 \\
\hline India & 52 billion of dollars & 131 \\
\hline Australia & 14.6 billion of dollars & 32 \\
\hline
\end{tabular}

\section{STRUCTURE AND DYNAMICS OF THE PROJECT FINANCE}

Structure of project finance represents a combination of debts, investment and loans, where service of debt primarily depends on profit created by the project itself. Project sponsors establish a project company in form of joint venture that will be the owner of funds and manage the project. Project company, not sponsors, borrow the financial 
funds from banks, needed for the project implementation. Project does not have direct impact on balance of sponsors or their loan credibility. Project finance demands creation of complex framework of internally connected contracts.

Project finance mechanism according to the Bassel regulations in Serbia foresees: financing of power plants, mines, processing industry, oil sources, telecommunications, media and technology; IPRE (Income Producing Real Estate) - refers to loans for construction or purchase of: business and office space, residential buildings, hotels, hypermarkets and shopping malls, complexes of cinemas, technological parks; financing of buildings - includes financing the purchase of movable assets, such as: airplanes, ships, trains, vehicle fleet, satellites; financing of goods - refers to financing the stocks, spare goods in trade, oil, metals, wheat, etc.

Project finance of money is a long term financing of large infrastructural and industrial projects based on the projected cash flow. Project finance structure usually includes a serial of shareholder investors and banks that will provide loans for the project. Very descriptive structure and dynamics of project finance was given by the General Director of Princepation Pacific Group and lecturer at the Euro money institute of Finance Thomas H. Pule, who defines a concept of project finance as follows: sponsor is a head, contractors and operators are wings, project company is a body, suppliers and buyers are weapons, and banks are legs. [11].

When the project finance is analyzed, it is significantly different than classic loaning. The main characteristic is that return of invested funds is expected from money profit made by project itself, not by debtor. Success of project depends on success of investment. Classic assessment of debtor's solvency, based on his financial report, does not contribute much when decision is made whether to finance the project or not. In that context, for the sake of project implementation, a new company is established for special purposes, which often does not have any balance or have them insufficiently.

Structure of specific investment project foresees that return is to be made from cash flow created by the project. Examples for such projects are: construction of buildings, mines, factories, roads, gas pipelines, water pipelines, ships, hospitals, schools, etc. Project finance is different than traditional form of financing, because creditors see the funds and cash flows of the project as source for return the inve-sted funds. At the project finance, return of invested funds most frequently does not depend on other property and income of debtors or project sponsors. Risk of debtor oneself is not so relevant as it is at regular loan. Loan analysis is composed of the project effectiveness assessment and project risk identification and management. Center of analysis is a project, not a debtor. A debtor is often a company for special purposes whose exclusive property is a project, and the only source of funds is a loan taken for the project funding. In case of large value projects, the role of creditor is often taken by several banks, so-called syndicated financing. At the project finance, the most important is an investment return period which defines a number of years needed to return the initial investments into project.

\section{CHARACTERISTICS OF \\ THE PROJECT FINANCE IN THE REPUBLIC OF SERBIA}

Project finance all over the world, especially with regards to the infrastructural projects, represents large financial investments followed by high level of commercial, political and financial risks. Serbia started its transitional process in economy in 2000. Up to date, the economic, finan- 
cial and political problems have been reality of the Serbian economy. Under circumstances of modest domestic accumulation, the significant foreign funds were needed for implementation of large investment projects throughout Serbia, as well as high foreign debt which limits the possibilities of direct loan indebtedness of our state that was practically the only source of international financing for these projects so far. On the other hand, the international funding of certain number of priority infrastructural and other investment buildings, with necessary level of commercial profitability, on principles of project finance and various types of partnership between the private and public sector, concessions and other types, would enable their construction without the new loans taken by the state, since the project itself would be indebted, and its property would be a guarantor for the debt. Anyway, an overview of the direct foreign investments in Serbia in the period from 2007 to 2014 indicate that arrival of foreign direct investments may play a key role in economic recovery of the Republic of Serbia, where a significant place may be taken by the model of project finance through concessions, public and private partnership, etc., Table 2.

Table 2 Direct foreign investments in Serbia 2007 - 2014

(in millions of euros) [15]:

\begin{tabular}{|l|c|c|c|c|c|c|c|c|}
\hline Year & 2007 & 2008 & 2009 & 2010 & 2011 & 2012 & 2013 & 2014 \\
\hline $\begin{array}{l}\text { Direct } \\
\text { foreign } \\
\text { investments }\end{array}$ & 3,219 & 2,711 & 2,100 & 1,278 & 3,544 & 1,009 & 1,548 & 1,500 \\
\hline
\end{tabular}

Regarding to the concept of project finance in the Republic of Serbia, it is followed by various types of risks that accompany character of the economy of Serbia. Various techniques of the project finance in the countries of the South-Eastern Europe, with the special emphasis on Serbia, have been applied mainly in the sectors of traffic and energetic. These projects rely on financing in foreign currency and they use technique of project finance, since their outputs are intended for the global market and they make profit in foreign currency. In our country, there are certain market risks that impact the outcome of most of the projects, therefore, the investors decide on the project finance in the sectors where profit may be defined and guaranteed in most of the cases. One of such investments, which is the focus of attention, is construction of the second phase of gas warehouse in Banatski dvor and Srpski Itebej, capacity of billions of cubes of gas. Srbija Gas and Gasprom also consider the construction of co-generative gas plants in Belgrade, Novi Sad, Paracin and Nis.

Serbia started to apply the project finance at the end of 2004, and during 2010 there were less than ten banks that offered such service on the Serbian market. [12]. With regards to this model and manner of servicing, the project finance through loans, banks should be primarily interested in value of the project and whether it is reasonable. When it comes to perspective of the project finance, it may be anticipated that in the incoming period, the domestic banks will start to follow construction and renting of small hotels of middle category in Belgrade, run by the expe- 
rienced domestic or international management, whose business will service the debt in as short period as possible. One more interesting model or, better to say, future of the project finance are media in Serbia. According to our opinion, the most successful financial institution that was the first one to actively apply the model of project finance in Serbia is the Unicredit
Bank. This bank approved a long-term investment loan of 12.7 million euros to the company HVAC Retail d.o.o., for construction the outlet center in Indjija and thus, confirmed that it remains devoted to the Serbian market and development of the local economy despite conditions of changeable economic environment and unstable market circumstances.

Table 3 The largest projects in Serbia implemented through the project finance in Serbia from $2010-2012$ [13]

\begin{tabular}{|l|l|l|l|l|}
\hline \multicolumn{1}{|c|}{ Project } & \multicolumn{1}{|c|}{ Investor } & \multicolumn{1}{c|}{ Type of project } & Year & \multicolumn{1}{c|}{$\begin{array}{c}\text { Value of } \\
\text { investment }\end{array}$} \\
\hline $\begin{array}{l}\text { Zeland, } \\
\text { Dedinje }\end{array}$ & Koling AD & $\begin{array}{l}\text { Residential complex, } \\
23000 \mathrm{~m}^{2}\end{array}$ & 2010 & $\begin{array}{l}35 \text { millions of } \\
\text { euros }\end{array}$ \\
\hline $\begin{array}{l}\text { Stepa } \\
\text { Stepanović }\end{array}$ & $\begin{array}{l}\text { Government of } \\
\text { the Republic of } \\
\text { Serbia }\end{array}$ & $\begin{array}{l}\text { Construction of } \\
\text { apartment building } \\
\text { complex }\end{array}$ & 2012 & $\begin{array}{l}112 \text { millions of } \\
\text { euros }\end{array}$ \\
\hline $\begin{array}{l}\text { Outlet Center } \\
\text { Indjija }\end{array}$ & HVAC Indjija & $\begin{array}{l}\text { Construction of shopping } \\
\text { mall, surface } 30000 \mathrm{~m}^{2}\end{array}$ & 2012 & $\begin{array}{l}24 \text { millions of } \\
\text { euros }\end{array}$ \\
\hline
\end{tabular}

\section{CONCLUSION}

Nowadays, China is very interesting investor for our country, and it has already started to invest at special targets through several projects. When it comes to potential endeavors in scope of the project finance by the Chinese companies, they will probably be candidates for cooperation with Serbia, being a Balkans country that plans to construct a navigable canal Belgrade - Thessaloniki. Future project sponsors in Serbia are very significant from aspect of economy such is Serbia. Therefore, there is a proposal that if we want to have greater inflow of funds for projects in the future, we need to be more oriented towards banks and sponsors coming from China, India and other countries, since their economic growth in 2014 was $8.2 \%$ in China, and $6.2 \%$ in India [14].
Unfortunately, the project finance in Serbia is still in its initial phase, even though we officially started with the project finance in 2005 , because we have not reached the standards that would enable a successful implementation. Serbia nowadays lacks those standards, mixture of legal and economic components, which are: upgrading or, better to say, creation of our legal and institutional frameworks with special emphasis on utilization the competences and financial possibilities of our public and private sector, as well as attraction of foreign investments, which were very few since the beginning of 2016. So, the legal, economic and political aspects have a key impact on efficient use the project finance in the Republic of Serbia. 
There are a lot of successful examples of the project finance in Europe, and all we need to do is to learn positive lessons from those projects and to understand what their impact on development of those economies was. The basic motive for potential investors in Serbia primarily should be that the capital investment has to be made into those fields where it is certain that profit and income exceed the price of investment. In fact, those are projects associated with the smallest risks, and in our country those are infrastructural projects, as well as investments into renewable energy resources.

Models of project finance with all its shortcomings and advantages should stand behind initiation of investment cycle in Serbia nowadays. Moreover, the economic literature about this filed teach us that utilization of the project finance and its development has an extraordinary importance for economy. What has to be realized about project finance is that we have to approach it with a syntagm that the price of the project is not a market price, but it is always a realistic price and thus, under given circumstances, risks have to be distributed to two, three or more participants, even to the state that should provide the additional guarantees in order to attract serious investors in the future.

\section{REFERENCES}

[1] See more details on this: Vinter, G. and G. Price (2002), Project Finance: A Legal Guied, Sweet\&Maxwell, London, 2006, ssl. See details on project finance Yescombe, E, R., Prin-ciples of Projecting Finance, Academic Press, London, Boston

[2] Switala H., The Role of Project Finance in Obtaining Sufficient Funding for Successful Completion of Your Project, Development Bank of Southern Adrica, V International
Conference in Southern Africa, 2010, p. 3-5.

[3] Gatti S., Project Finance in Theory and Practice, $2^{\text {and }}$ Edition, British Library Catologuing, in Publication date, United States of America, 2012, p.21.

[4] Worenklein, J. Jacob, The Global Crises in Power and Infrastructure Lessons Learned and New Directions, The Journal of Structured Finance, Volume 9, Spring 2003, No 1, pp. 7-11.

[5] Vikas, Srivastava, Ashish, Kumar, Financing Infrastructure Projects in India from Corporte Funance to Project Finance, International Research Journal of Fiance and Economics, 2010, p. 11, Data and information available on website http://eurojournals.com/finance.html

[6] Rainer, Kistner and Henry Price, Financing Solar Thermal power Plants, Lahaina, Maui, Hawaii, International Conference in South America, April 11-15, 1999, p. 2.

[7] Benjamin C. Esty, Why Study Large Projects? An introduction to Research on Project, Finance European Financial Management, Vol. 10, No 2, 2004, pp. 213-224.

[8] K.A.K. Devapriya and H. Wilhelm Alfen, Role of Institutional Arrangements in Financing Project Companies in Asia, American Journal of Economic, October 2, 2003, pp. 23-27.

[9] B. C. Esty, The Economics Motivations for Using Project Finance, Harvard Business School, Februay 14, 2003, pp. 1-42.

[10] See more details on this: Anastasia Slivker What is Project Finance and How Does it Work, April 2011, pp. $1-27$.

[11] G. M. Bodna, Project Finance Teaching Notep, FNCE 208/731, Wharton School, Euromoney Institute of Finance, 1996, p.8. 
[12] Barjaktarović L., Project Finance in Serbia, University Singidunum, Review, Vol. 5, No. 1, Belgrade (in Serbian)

[13] Rutić B., Development and Characteristics of the Project Finance as a Modern Bank Product for Economy,
University Singidunum, Belgrade, 2012, p. 48, or www.ekapija.com

[14] Report of IMF, Washington, 2013 (in Serbian)

[15] http://siepa.gov.rs/, accessed on 03/17/2016 